\title{
Transformation of Texaco and Barriers to Its Implementation
}

\author{
Shafi F. Al Dousari ${ }^{1}$ \\ ${ }^{1}$ Arab Open University/ UK Open University Partnership, P.O. Box\# 46599, Code\# 64016, Fahaheel, Kuwait \\ Correspondence: Shafi F. Al Dousari, Arab Open University/ UK Open University Partnership, P.O. Box\# 46599, \\ Code\# 64016, Fahaheel, Kuwait.
}

Received: September 2, 2019

Accepted: October 9, 2019

Online Published: October 21, 2019

doi:10.5539/ibr.v12n11p38

URL: https://doi.org/10.5539/ibr.v12n11p38

\begin{abstract}
Purpose: To evaluate the barriers for implementing learning policy to transform Texaco into a Learning Organization. Design/Methodology: The study has incorporated quantitative approach and distributed 200 questionnaires among the employees of Texaco, out of which 189 questionnaires were received with complete responses. The extent of paradigm shift to take place in Texaco was estimated by conducting personal interviews. Chi-Square and ANOVA test have been applied through SPSS on the dependent and independent variables. Findings: Non-Learning culture $(\mathrm{p}=0.000)$, Limited resources $(\mathrm{p}=0.001)$, Program Focus $(\mathrm{p}=0.00)$ and not discussing the un-discussible $(\mathrm{p}=0.00$ ) have been found as the main barriers in the way of transformation of Texaco as a learning organization. Research Implications: The implication of this research can help to adopt the positive transformational changes of the company. Practical Implications: The findings can help Texaco to identify the potential barriers and mitigate their influence on their business operations. Social Implication: Positive societal influence can be significant in improving the competitive strategy of Texaco. Originality: The changes in the organizational process can be implemented to improve the learning policy of Texaco.
\end{abstract}

Keywords: barriers, learning organization, learning policy, non-learning culture, Texaco, transformation

Article Classification: Research Paper

\section{Introduction}

Texaco is an American oil producing company and has partnered with the Kingdom of Saudi Arabia (KSA) for more than six decades. Texaco has committed to improving the performance of its processes through better learning approaches. The strategic vision is associated with the goals and mission of the organization; therefore, there is a need to provide a way for the organization (Scott and Davis, 2015). The concept of learning organization appeared in the late 1990s that represented an evolution of the organizational learning perspective as a result in building up of transformational change in firms (Stead and Stead, 2013). Learning and knowledge are forced to move away from the simplest mechanism for managing the on-going change. The Learning Organization paradigm challenges organizations to use knowledge as a basis for competitive strategy and to use organizational learning as the bedrock for their survival and growth (Cummings and Worley, 2014; Jones and Sallis, 2013). It involved the ability of a human to appreciate and discriminate the judgments. A learning organization needs to move towards its vision decisively and develop a unique design.

The concept of the learning organization is positively associated with the development of normative models and methodologies to create change in direction of the improved learning procedures. It is more concerned towards understanding the processes and nature of learning organization. Moreover, a collective mind shift at all the levels is needed to become a successful learning organization. Transformation taking place in an organization improves the learning ability of the organization and thus, empower organizations to perform better (Daryani et al., 2014). On the contrary, the most important factor that enhances the ability and performance of organizations is an improved learning environment. Hence, work diversity acquires vital suggestions from the organization, which helps in improving the performance of the organization. To this end, work diversity can enrich the organization with the cohort of new fresh ideas and creating a positive image of the organization (Amoo and Friedman, 2002).

The organizational culture enables the knowledge-sharing behavior among employees to contribute to the spirituality and learning culture of the workplace (Sorakraikitikul \& Siengthai, 2014). Organizations are continuously feeling the urge to introduce changes, innovation or transformation in their organizational practices. To this end, the culture was defined as the key source in shaping the overall intentions and practices of employees 
working in an organization (van Breda-Verduihn \& Heijboer, 2016). Learning is the key source to improve and increase the success ratio of an organization. A strong learning platform will equip the employees with the correct knowledge; thus, creating a strong breeding ground for the learners. Through such initiatives, the overall quality of the employees can also be improving and the learning will also help them in making the right decisions (Winkler \& Fyffe, 2016).

Resource development, on the other hand, also plays a crucial role in the formulation of learning organizations. Low-resource can significantly influence any department willing to improve its learning capabilities (Leufvén et al., 2015). Learning organizations requires monetary funds, skilled and trained work force which can help in equipping the employees with enhanced knowledge (Leufvén et al., 2015). The importance of learning organization cannot be ignored and its huge impact on the performance of the organization cannot be avoided. However, organizations suffer from a number of limitations, which hinder the implementation of the learning organization.

\section{Problem Statement}

Without learning, the organizations do not succeed and expand. In terms of oil and gas industries, the companies' high reliance is upon competitive advantage and its tangible and intangible assets (Garcia et al., 2014). Similarly, learning is also termed as a crucial factor in enhancing the competitive advantage of oil industries (Cummunigs and Worley, 2014; Jones and Sallis, 2013). Such that, it is necessary to enhance the learning abilities of the employee through various means. However, the implementation of the learning environment is subjected to ample problems. The oil industry has passed through a number of transformations from research department to drilling; however, knowledge management in such sectors is still subjected to the issues occurring from human resource policies, departmental cooperation and organizational structure (Ramanigopal, 2012). On the contrary, leadership control, participation, management commitment, and behavioral control node also significantly influence the learning and work behavior of employees (Jitwasinkul et al., 2016). Similarly, in the same context, the organizational paradigm of Texaco began to shift in 2000. Initially, the employee self-development program was implemented and every employee was encouraged to take part in it to enhance learning. Texaco plans to build learning centers by providing journals, books, training material, and computer systems throughout the organization. It is important to investigate the success of Texaco in shifting to become the learning organization.

\section{Significance of the study}

Learning organization can also be implemented as a learning technique that involves much more than information transfer. Learning organization cannot be imposed but it requires an internal desire to change and learn. Moreover, knowing, learning and changing is an interdependent and complex phenomenon that requires managers and researchers to understand the concept embedded in the learning organization idea before implementing it. If an organization does not understand or accept the transforming perspective embedded in this notion, it might not be linked with this new concept, in a nomothetic manner. Therefore, the possible changes might be the superficial and reactive ones that are not sustainable in long term. To this end, it can be suggested that the following research will help the practitioners and the stakeholders to adopt strategies while incorporating learning into an organization. By evaluating the case of Texaco, the parameters discovered in it can be resolved while developing learning strategies for other organizations.

\section{Aim of the study}

The study aims to evaluate the barriers to implement a learning policy for the transformation of Texaco as a learning organization to overcome limited potential. Additionally, this study aims to facilitate Texaco to convert into a learning organization from its usual training-oriented business culture.

\section{Literature Review}

The concept of the learning organization is extremely vast; however, it is still undefined. Several authors have discussed regarding the concept of learning organization to make organizations realize the importance of learning in an organization. Garrett (1995) discussed the importance of learning organization and showed that the key ideas regarding learning organization became popular in the years after World War. The organizations were keen toward earning more money by hiring a large workforce due to the devastation of war. Hence, the entire developing world was moving toward more work and organization. To this end, it did not take much time for the researchers to actually implement the theory.

The concept holds several definitions in the history, with regard to it, Mintzberg (1989) shows that the learning organization has significant impacts on its environment. Moreover, Mintzberg (1989) showed how learning can influence the normal and routine operations carried out in an organization. Therefore, the concept of learning 
organization suggests that a learning organization not only helps the organization to grow and gain success by formulating a learning culture, but it also influences the parameters which account for the success of an organization. Moreover, Pedler, Burgoyne and Boydell (1996) also showed that the learning organization creates opportunities for all the individuals working in an organization to learn and transform themselves. Hence, the learning organization can play a crucial role in transforming the overall structure and environment of an organization.

Bratianu (2015) discussed that the learning organization is based on a conceptual background. The study showed that organizational learning can only be implemented in organizations by institutionalizing, interpreting, integrating, and intuiting. Moreover, leadership also plays a key role in integrating this phenomenon into organizations. The process can be single-looped or double-looped, hence, can be an adaptive or a generative process, respectively. The learning organization implements organizational learning to transform the entity into a knowledge hub, hence building up the competitive advantage for the organization. To second this statement, Farrukh and Waheed (2015) also conducted a study to show that a learning organization can be defined as an entity that learns through its members, i.e. both individually and collectively. The learning process helps the organization to build competitive advantage, which in turn leads to the self-development and information sharing among employees.

Despite the advantages of organizational learning, it is still subjected to a number of factors that influence its implementation in organizations. Knowledge sharing, resources etc. play an important role while implementing organizational learning. To this end, Hasanzadeh et al. (2014) showed that knowledge sharing is a powerful tool which leads to the development of an organization and its employees. Knowledge sharing can be considered as one of the tools, which are used to empower employees and the operations of an organization. However, communication flow, organizational strategy and inter-team communication significantly influences the overall knowledge sharing within the organization. The study recommended that organizations must be given an opportunity to share knowledge, hence, adequate and robust strategies must be developed to ensure the overall positive outcome from organizational learning.

Rizescu and Tileag (2016) also suggested that change in the organization is only brought by constant and continuous struggle. Both domestic stability and operating environment is necessary for an organization to build up their competitive advantage. Hence, organizations must learn to implement a robust organizational structure, which ensures flexibility and learning environment within an organization. Therefore, the organizational development greatly depends on the organizational changes being implemented with respect to the learning environment. The development of strategies and organizational structures significantly influence the learning environment. Moreover, the economic efficiency of an organization also hinders the implementation of learning in an organization. Thus, overall behavior and management system must also be renewed to ensure successful implementation of organizational learning.

Another study conducted by Noor et al (2014) showed that there are several organizational, individual and IT related factors that hinder the implementation of knowledge sharing in an organization. These factors were organizational support, trust, reward system, organizational culture, organizational structure, subjective norm, self-efficiency, information system social media use, and technical infrastructure. The factors were found to be the major reason for the inefficiency of organizational learning. Hence, the study concluded that organizations must play a key role to overcome the organizational, individual and IT-related problems to ensure the success of knowledge sharing. Knowledge sharing is the interaction between technology, organization, and people; therefore, a firm and robust connection must be developed that overcome the issues related to organizational learning.

Razmerita et al (2016) also showed that social media communication can also enhance the overall performance of an organization by ensuring a sound transfer of knowledge within an organization. However, the study described factors which affect the participation of employees in the social media enterprise. Moreover, the study discussed a motivational perspective which is beneficial for improving the knowledge sharing behavior of organizations. The intrinsic and extrinsic factors were identified in the study which influences the overall knowledge sharing behavior of the employees. These factors include working experience, lack of trust in colleagues, management encouragement, and behavioral changes. Hence, by developing strategies for such factors, organizational learning can be significantly implemented to increase the competitive advantage of firms.

\section{Methodology}

The study aims to facilitate Texaco to convert into a learning organization from its usual training-oriented business culture. A questionnaire was structured to gather the responses of employees to evaluate the barriers faced in the implementation of learning policies in Texaco. A small pilot study has also been conducted to improve the 
construction of the questionnaire with 15 pre-selected respondents. Hence, the response rate for the pilot study was calculated to be $100 \%$. There were appropriate suggestions as to content and format. The original questionnaire differs from the final questionnaire that was distributed to the sample population, which were the employees of Texaco.

\section{Study Sample}

A total sample size selected for the study was 200 from a sample of 1950 employees. The sample size included all the employees working in the organization, both national and non-national Saudi employees.

\section{Data Collection}

Questionnaires were distributed among 200 sample of the study, out of which only 189 responses were received from the Saudi and non-National employees of Texaco. 5 questionnaires were not filled properly, and the remaining were not returned at all. The questionnaire was distributed to assess the awareness among employees towards a Learning Organization. The questionnaire included information which was used to evaluate the inclination of employees toward the adoption of organizational learning. On the other hand, personal interviews were conducted to estimate the extent of paradigm shift (from traditional training culture to a Learning Organization) supposed to take place in Texaco.

\section{Data Analysis}

Statistical Package of Social Sciences (SPSS) version 20.0 has been used to analyze the data obtained from the responses of employees. Chi-Square test was applied on the dependent variables against independent variables to check the association between the factors. ANOVA test was applied to examine the influence of independent variables on dependent variables. The dependent variables taken for the study were "There is a need to evaluate the barriers in the ways of implementing learning policy in Texaco" and "The barriers are the main cause of the lack of learning environment in Texaco" and the independent variables were program focus, resistance to change, Non-learning culture, limited resources and not discussing the undiscussable. Thus, the data analysis derived the limit to which the following variables influenced the concept of Learning Organization.

Table 1. Pearson Chi-Square Test for Dependent variable "Need to evaluate the barriers"

\begin{tabular}{|c|c|}
\hline \multicolumn{2}{|c|}{ There is a need to evaluate the barriers in the ways of implementing learning policy in Texaco. } \\
\hline Independent Variables & Pearson Chi-Square \\
\hline $\begin{array}{l}\text { Qualification improvement and the advanced training } \\
\text { programs should be made available to every employee. }\end{array}$ & 0.907 \\
\hline $\begin{array}{c}\text { The HR communication campaign is vital to build the } \\
\text { relationship and increase the trust level between the } \\
\text { departments and HR. }\end{array}$ & 0.028 \\
\hline $\begin{array}{l}\text { There should be a system to measure the employee's } \\
\text { skills/capabilities and then provide with an action plan for their } \\
\text { development }\end{array}$ & 0.002 \\
\hline $\begin{array}{l}\text { Management should encourage the employees to be creative } \\
\text { and innovative in their thinking and performance of tasks. }\end{array}$ & 0.000 \\
\hline $\begin{array}{l}\text { Teamwork is always the driving force behind the effectiveness } \\
\text { and efficiency within the organization. }\end{array}$ & 0.002 \\
\hline $\begin{array}{l}\text { All the employees deserve respect regardless of how different } \\
\text { they are in improving the business culture. }\end{array}$ & 0.021 \\
\hline $\begin{array}{l}\text { New ideas and experiment are provided before risking large } \\
\text { scale implementation. }\end{array}$ & 0.230 \\
\hline $\begin{array}{l}\text { Financial support should be provided for the learning and also } \\
\text { to experiment new ideas. }\end{array}$ & 0.001 \\
\hline $\begin{array}{l}\text { The negative attitude of an employee is bringing down spirits } \\
\text { of the organization but no one will consider this problem for } \\
\text { fear of retribution. }\end{array}$ & 0.000 \\
\hline $\begin{array}{l}\text { Everyone has a shared but unspoken understanding regarding } \\
\text { the issues. }\end{array}$ & 0.002 \\
\hline
\end{tabular}

\section{Results and Discussion}

Pearson Chi-square test has shown the association between the variables according to the responses obtained from the employees of Texaco. The results of the study have shown the association between the dependent and independent variables. The level of significance set for the study was 0.05 that indicates a $5 \%$ risk of concluding the difference that exists. Table 1 has shown the results of the first dependent variables that is "There is a need to 
evaluate the barriers in the ways of implementing learning policy in Texaco" against the independent variables that is program focus, resistance to change, Non-learning culture, limited resources and not discussing the undiscussable.

There were two questions that were related to the program focus. For instance, "qualification improvement and the advanced training programs should be made available to every employee" has a statistically insignificant outcome as the $\mathrm{p}$-value observed through the results was greater than the level of significance $(0.907>0.05)$. The $p$-value obtained for the second question regarding program focus has been found statistically significant as it has been found less than the level of significance $(0.028<0.05)$.

Table 1 has also shown the association between the dependent variable and independent variable that is "resistance to change". It has been observed that the responses for both questions regarding resistance to change have been found statistically significant as the p-values for both responses were statistically significant. The results concluded that management should encourage their employees to be innovative and bring new ideas into their performance. There should be a system to measure the employee's skills/capabilities and then provide with an action plan for their development. This has concluded that resistance to change is one of the barriers in the way of learning culture within Texaco. Moreover, Jones and Van de Ven (2016) showed that with time the resistance to change increases. Such that, organizational changes are not effectively adopted by organizations without any resistance. Moreover, the study also reported that it is necessary to overcome this resistance among employees due to the negative effects. Also, the study showed that leadership can have a significant influence on the overall performance of the organization. Moreover, Ebonkeng (2018) also illustrated the importance of change in an organization. The study highlighted that without change, an organization cannot foster according to the changing trends.

The responses of the employees were found in favor of teamwork as the association between the dependent and independent variable regarding teamwork has been found statistically significant. It has also been found that all the employees deserve respect regardless of how different they are in improving the business culture as the p-value found is less than the level of significance $(0.002<0.05)$. The results have concluded that Non-learning culture might also be one of the barriers that might cause hindrance in maintaining a learning organization. Limited resources might also be one of the barriers as the results have shown that there were no new experiments or ideas provided before risking large-scale implementation in most of the cases according to the employees. The results have also shown a statistically significant association between the variables $(0.001<0.05)$. This indicated that limited resources might also be one of the major concerns in the transformation of Texaco as a learning organization. Moreover, it has also been found that the negative attitude and behavior of employees can also decrease the spirits of the organization but no one considers this problem for fear of retribution. The results have been found statistically significant $(0.002<0.05)$, indicating that there is an existence of shared but unspoken understanding regarding the issues among the employees (Table 1).

Snyder (2016) conducted a study that reported results consistent with the findings of the current study. The study also reported the importance of organizational culture, leader and management in the organization. The study reported that organizational culture can significantly impact the overall performance of the organization thus, leading to reduced knowledge sharing among employees. van Breda Verdujin and Heijboer (2016) also reported that learning culture significantly influences the overall performance of the organization. To this end, it can be concluded that non-learning culture can have a severe impact on the learning environment of the organization. On the other hand, Beech et al. (2017) showed that the participation of employees can be subjected to the lack of resources available to them. Moreover, Adeniji et al. (2016) reported the importance of attitudes of employees with regards to the organizational change. The results showed that employee commitment is necessary to significantly incorporate organization learning. Hence, the findings of such studies were found to be consistent with the findings of the current study. 
Table 2. Pearson Chi-Square Test for Dependent variable "Barriers are the main cause of lack of learning Environment"

\begin{tabular}{|c|c|}
\hline \multicolumn{2}{|c|}{ The barriers are the main cause of the lack of learning environment in Texaco. } \\
\hline Independent Variables & Pearson Chi-Square \\
\hline $\begin{array}{l}\text { Qualification improvement and the advanced training } \\
\text { programs should be made available to every employee. }\end{array}$ & 0.045 \\
\hline $\begin{array}{c}\text { The HR communication campaign is vital to build the } \\
\text { relationship and increase the trust level between the } \\
\text { departments and HR. }\end{array}$ & 0.000 \\
\hline $\begin{array}{l}\text { There should be a system to measure the employee's } \\
\text { skills/capabilities and then provide with an action plan for their } \\
\text { development }\end{array}$ & 0.000 \\
\hline $\begin{array}{l}\text { Management should encourage the employees to be creative } \\
\text { and innovative in their thinking and performance of tasks. }\end{array}$ & 0.000 \\
\hline $\begin{array}{l}\text { Teamwork is always the driving force behind the effectiveness } \\
\text { and efficiency within the organization. }\end{array}$ & 0.000 \\
\hline $\begin{array}{l}\text { All the employees deserve respect regardless of how different } \\
\text { they are in improving the business culture. }\end{array}$ & 0.000 \\
\hline $\begin{array}{c}\text { New ideas and experiment are provided before risking large } \\
\text { scale implementation. }\end{array}$ & 0.000 \\
\hline $\begin{array}{l}\text { Financial support should be provided for the learning and also } \\
\text { to experiment new ideas. }\end{array}$ & 0.001 \\
\hline $\begin{array}{l}\text { The negative attitude of an employee is bringing down spirits } \\
\text { of the organization but no one will consider this problem for } \\
\text { fear of retribution. }\end{array}$ & 0.119 \\
\hline $\begin{array}{c}\text { Everyone has a shared but unspoken understanding regarding } \\
\text { the issues. }\end{array}$ & 0.000 \\
\hline
\end{tabular}

Table 2 has considered "The barriers are the main cause of the lack of learning environment in Texaco" as a dependent variable. The association between the dependent variable with independent variables has been examined through the Pearson chi-square test. According to the results, it has been indicated that program focus might be one of the causes in the transformation of Texaco.

The results obtained for the Program focus are statistically significant $(0.045<0.05)$ and $(0.000<0.05)$; therefore, indicated that there is a need of program focus for the transformation of Texaco. The results for the dependent variable "barriers are the main cause of the lack of learning environment in Texaco" has been found statistically significant $(0.000<0.05)$. This has indicated that the main cause in the transformation of Texaco might be the resistance to change and there should be a system to measure the skills and capabilities of employees and provide an action plan for their development.

The results have also indicated that there is a non-learning culture within Texaco and there should be teamwork activities and respect should be given to the employees regardless of how different they are in enhancing the business culture. Limited resources have also been found as one of the chief barriers in the transformation of Texaco. There were statistically significant results found regarding the understanding issues within Texaco. According to the responses, there should be shared but spoken understanding regarding the issues within the organization.

Table 3 has shown the results obtained through the ANOVA analysis for the dependent variable "there is a need to evaluate barriers in the transformation of Texaco". The results have indicated that there is a need to encourage employees to be creative and implement new ideas as the p-value for this independent variable has been found less than the level of significance $(0.014<0.05)$. Employees deserve respect regardless of how different they are in improving the business culture that has also been found to be statistically significant $(0.001<0.05)$. Financial support should be provided by the organization to bring creative and innovative ideas from employees and implement them to enhance the culture of an organization $(0.000<0.05)$. The negative attitudes and shared but unspoken understanding have also been found statistically significant $(0.000<0.05)$. The results from ANOVA have indicated that the non-learning culture, limited resources and not discussing the un-discussable might be the main barriers to the transformation of Texaco. 
Table 3. Three-Way ANOVA test for dependent variable "Need to evaluate the barriers"

\begin{tabular}{|c|c|c|c|c|c|}
\hline \multicolumn{6}{|c|}{$\begin{array}{c}\text { Tests of Between-Subjects Effects } \\
\text { Dependent Variable: Need to evaluate the barriers }\end{array}$} \\
\hline Source & $\begin{array}{l}\text { Type III Sum of } \\
\text { Squares }\end{array}$ & df & Mean Square & $\mathbf{F}$ & Sig. \\
\hline Corrected Model & $17.901^{\mathrm{a}}$ & 33 & .542 & 9.686 & .000 \\
\hline Intercept & 2.115 & 1 & 2.115 & 37.762 & .000 \\
\hline $\begin{array}{l}\text { Qualification improvement and } \\
\text { advanced training programs }\end{array}$ & .111 & 3 & .037 & .663 & .576 \\
\hline $\begin{array}{c}\text { System to measure the employee's } \\
\text { skills }\end{array}$ & .036 & 3 & .012 & .215 & .886 \\
\hline $\begin{array}{l}\text { Encourage employees to be } \\
\text { creative }\end{array}$ & .612 & 3 & .204 & 3.643 & .014 \\
\hline HR communication campaign & .316 & 4 & .079 & 1.410 & .233 \\
\hline Teamwork is always driving force & .233 & 4 & .058 & 1.041 & .388 \\
\hline Employees deserve respect & .850 & 2 & .425 & 7.587 & .001 \\
\hline $\begin{array}{l}\text { New ideas and experiment are } \\
\text { provided }\end{array}$ & .638 & 4 & .160 & 2.850 & .026 \\
\hline $\begin{array}{l}\text { Financial support should be } \\
\text { provided }\end{array}$ & 1.944 & 3 & .648 & 11.569 & .000 \\
\hline $\begin{array}{l}\text { Negative attitude brings down } \\
\text { spirit of Organization }\end{array}$ & 1.258 & 3 & .419 & 7.486 & .000 \\
\hline $\begin{array}{l}\text { Shared but unspoken } \\
\text { understanding }\end{array}$ & 2.604 & 4 & .651 & 11.626 & .000 \\
\hline Error & 8.681 & 155 & .056 & & \\
\hline Total & 285.000 & 189 & & & \\
\hline Corrected Total & 26.582 & 188 & & & \\
\hline \multicolumn{6}{|c|}{ a. $\mathrm{R}$ Squared $=.673($ Adjusted R Squared $=.604)$} \\
\hline
\end{tabular}

Table 4. Three-Way ANOVA test for dependent variable "Barriers are the main cause of the lack of learning environment"

\begin{tabular}{|c|c|c|c|c|c|}
\hline \multicolumn{6}{|c|}{$\begin{array}{c}\text { Tests of Between-Subjects Effects } \\
\text { Dependent Variable: barriers are the main cause of the lack of learning environment }\end{array}$} \\
\hline Source & $\begin{array}{l}\text { Type III Sum of } \\
\text { Squares }\end{array}$ & df & Mean Square & $\mathbf{F}$ & Sig. \\
\hline Corrected Model & $19.151^{\mathrm{a}}$ & 33 & .580 & 35.385 & .000 \\
\hline Intercept & 8.865 & 1 & 8.865 & 540.494 & .000 \\
\hline $\begin{array}{l}\text { Qualification improvement and } \\
\text { advanced training programs }\end{array}$ & .152 & 3 & .051 & 3.083 & .029 \\
\hline $\begin{array}{l}\text { System to measure the } \\
\text { employee's skills }\end{array}$ & .014 & 3 & .005 & .278 & .841 \\
\hline $\begin{array}{l}\text { Encourage employees to be } \\
\text { creative }\end{array}$ & .088 & 3 & .029 & 1.795 & .150 \\
\hline HR communication campaign & .098 & 4 & .024 & 1.489 & .208 \\
\hline $\begin{array}{l}\text { Teamwork is always driving } \\
\text { force }\end{array}$ & .736 & 4 & .184 & 11.213 & .000 \\
\hline Employees deserve respect & .137 & 2 & .068 & 4.163 & .017 \\
\hline $\begin{array}{l}\text { New ideas and experiment are } \\
\text { provided }\end{array}$ & 2.559 & 4 & .640 & 39.002 & .000 \\
\hline $\begin{array}{l}\text { Financial support should be } \\
\text { provided }\end{array}$ & .107 & 3 & .036 & 2.174 & .093 \\
\hline $\begin{array}{l}\text { Negative attitude brings down } \\
\text { spirit of Organization }\end{array}$ & .072 & 3 & .024 & 1.456 & .229 \\
\hline $\begin{array}{l}\text { Shared but unspoken } \\
\text { understanding }\end{array}$ & .048 & 4 & .012 & .733 & .571 \\
\hline Error & 2.542 & 155 & .016 & & \\
\hline Total & 264.000 & 189 & & & \\
\hline Corrected Total & 21.693 & 188 & & & \\
\hline \multicolumn{6}{|c|}{ a. $\mathrm{R}$ Squared $=.883($ Adjusted $\mathrm{R}$ Squared $=.858)$} \\
\hline
\end{tabular}

Table 4 has shown the ANOVA test for dependent variable "Barriers are the main cause of lack of learning environment" against the independent variables of the study. The result observed for the variable program focus that is "Qualification improvement and advanced training programs" has been found statistically significant as the $\mathrm{p}$-value observed is found less than the level of significance $(0.029<0.05)$. Teamwork as a driving force 
$(0.000)$, new ideas and experiment $(0.000<0.05)$ as significant factors. This has shown that there is a need for teamwork and new ideas and experiments to be implemented within Texaco.

Texaco has teams that visit different sites collecting, identifying and circulating new information to implement best practices. These teams also work with local teams to implement best practices, concerning the contextual differences in different situations. It brings a new conceptualization to the organization and provides a new way of thinking and developing relationships within the organization (Evans et al., 2013). This concept also brings an idea that humanity is not considered in a deterministic way, instead an object can be considered as a creative and a proactive actor that is able to bring a social and individual change (Florida, 2014). Texaco has been found with the concepts and practices essential for learning organization and provides a practical and logical example for other organizations as well (Edwards, 2014). The present study has been conducted to evaluate the possible barriers Texaco could encounter, and to find the ways for how Texaco could overcome them. The main emphasis of Texaco is on managing and integrating knowledge throughout the company. Knowledge management does not seem to be the diverse program in Texaco, but rather an intrinsic part of the corporate policy and leadership idea. Texaco has certain job responsibilities that comprise of the participation in the communities and networks of practice. The participation in knowledge management activities is explicitly determined as an indicator of performance in the technology group of Texaco. However, there is no financial support for using the knowledge management at Texaco. Formal and Direct system are more common other than growth in the career of an employee in Texaco (Grant, 2013).

There must be limited resources provided to the employees so that they are able to bring new and innovative ideas and work as a team to drive the success of the organization. Learning culture should be developed within Texaco and all the employees must be given respect regardless of how different they are in improving the business culture. By implementing these, people might be able to continuously expand their capacity to create results they truly desire, new and expansive patterns of thinking could be nurtured, and people will be continuously learning how to teach (Christensen and Raynor, 2013). The main purpose of Texaco is to enhance the working conditions through effective methods for extracting crude oil and supply it to the rest of the world to achieve greater sustainability. To achieve the required goals, Texaco engages with the organizations and other public or private sector within the country.

\section{Limitations}

The study has provided significant results which can be used by the organizations seeking to incorporate learning in their organizations. Moreover, the performance of Texaco has also highlighted the importance of several actors that are necessary to implement organizational learning. However, despite the advantages of the study, it is still subjected to a number of limitations. The sample size of the study was small; therefore, future studies are encouraged to include a large sample so that proper and generalized results can be derived. The study did not discuss the factors associated with social media. With the advancement in technology, the organizations are moving towards the adoption of social media for learning purposes. The area is still subjected to a number of limitations which could have increased the significance of the study. The study has undertaken only one company whereas future studies can undertake more than one company to evaluate more generalized results.

\section{Conclusion}

This study has formed few novel goals to implement learning policies within the organization as a new management tool in managing the affairs of Texaco. Certain barriers have been found that might be the cause of hindrance in the transformation of Texaco as a learning organization. The concept and practices of the learning organization are not only good and advisable in Texaco, but they are also found to be practical and logical to an extent. Texaco can be considered as one of the organizations that believe in the concept of learning organization and the vision of Texaco calls for "Growing together, people and business". The employees of Texaco might be considered as the greatest motivation, who aims to explore, produce and market the resources entrusted to the organization. It is concluded that there should be an HR communication campaign to build the relationship and increase the level of trust between HR and different departments of the company.

The time is ripe for Texaco to recognize that its organizational practices and procedures were surely under the scope of the learning organization, but with some minor modifications. Moreover, it has been recommended that the learning organization must require systems to ensure that its own ideas and processes can be challenged and reviewed. Managers in any organization ought to be clearer about where the collective learning process takes place and where the consequent collective knowledge is located. 


\section{References}

Adeniji, C. G., Iyiola, O. O., Agboola, M. G., Akinbode, M., \& Epetimehin, S. (2016). Employees' Attitudes towards Organizational Change and Its Effects on Employee Commitment.

Amoo, T., \& Friedman, H. H. (2002). Workforce Diversity: The Key to Survival and Growth.

Beech, N., McGill, I., \& Brockbank, A. (2017). "Reflective learning in practice", in Reflective learning in practice. Routledge, pp. 30-40.

Bratianu, C. (2015). Organizational Learning and the Learning Organization. Organizational Knowledge Dynamics: Managing Knowledge Creation, Acquisition, Sharing, and Transformation. Hershey, PA: Information Science Reference, pp. 286-312. https://doi.org/10.4018/978-1-4666-8318-1.ch012

Christensen, C., \& Raynor, M. (2013). The innovator's solution: Creating and sustaining successful growth. Harvard Business Review Press.

Cummings, T. G., \& Worley, C. G. (2014). Organization development and change. Cengage learning.

Daryani, S. M., Ardabili, F. S., \& Amini, M. (2014). The study models of learning organization building. International Journal of Learning and Intellectual Capital, 11(4), 320-333. https://doi.org/10.1504/IJLIC.2014.066649

Ebongkeng, H. (2018). Organizational Change and Performance.

Edwards, J. (2014). Knowledge management in energy sector organizations. Handbook of Research on Knowledge Management: Adaptation and Context, 157. https://doi.org/10.4337/9781783470426.00019

Evans, P., Hassard, J., \& Hyde, P. (2013). Critical leadership: Leader-follower dynamics in a public organization. Routledge.

Farrukh, M., \& Waheed, A. (2015). Learning organization and competitive advantage-An integrated approach. Journal of Asian Business Strategy, 5(4), 73.

Florida, R. (2014). The Rise of the Creative Class--Revisited: Revised and Expanded. Basic Books (AZ).

Garcia, R., Lessard, D., \& Singh, A. (2014). Strategic partnering in oil and gas: A capabilities perspective. Energy Strategy Reviews, 3, 21-29. https://doi.org/10.1016/j.esr.2014.07.004

Garrett, B. (1995). An old idea that has come of age. People Management, 1, 25-27.

Grant, R. M. (2013). The development of knowledge management in the oil and gas industry. Universia Business Review, 40.

Hasanzadeh, S., Sarkari, M., \& Hasiri, A. (2014). Evaluation of Organizational Factors Affecting Knowledge Sharing in Work Teams. Indian Journal of Science and Research, 4(6), 259-263. https://doi.org/10.1016/j.ssci.2015.09.027

Jitwasinkul, B., Bonaventura H. W. H., \& Abdul, Q. M. (2016). A Bayesian Belief Network model of organizational factors for improving safe work behaviors in Thai construction industry. Safety science, 82, 264-273.

Jones, G., \& Sallis, E. (2013). Knowledge management in education: Enhancing learning \& education. Routledge.

Jones, S. L., \& Van de Ven, A. H. (2016). The changing nature of change resistance: An examination of the moderating impact of time. The Journal of Applied Behavioral Science, 52(4), 482-506. https://doi.org/10.1177/0021886316671409

Leufvén, M., Vitrakoti, R., Bergström, A., Ashish, K. C., \& Målqvist, M. (2015). Dimensions of Learning Organizations Questionnaire (DLOQ) in a low-resource health care setting in Nepal. Health research policy and systems, 13(1), 6. https://doi.org/10.1186/1478-4505-13-6

Mintzberg, H. (1989). "The structuring of organizations", in Readings in Strategic Management. Palgrave, London, pp. 322-352. https://doi.org/10.1007/978-1-349-20317-8_23

Noor, A. D., Hashim, H. S., \& Ali, N. (2014). Factors influencing knowledge sharing in organizations: A literature review. International Journal of Science and Research, 3(9), 1314-1319.

Pedler, M., Burgoyne, J., \& Boydell, T. (1996). The learning company: A strategy for sustainable development. London: McGraw-Hill. 
Ramanigopal, C. S. (2012). Knowledge Management for the Oil and Gas Industry: Opportunities and Challenges. Asian Journal of Business and Economics, 2(2), 4.

Razmerita, L., Kirchner, K., \& Nielsen, P. (2016). What factors influence knowledge sharing in organizations? A social dilemma perspective of social media communication. Journal of Knowledge Management, 20(6), 1225-1246. https://doi.org/10.1108/JKM-03-2016-0112

Rizescu, A., \& Tileag, C. (2016). Factors influencing continuous organizational change. Journal of Defense Resources Management, 2, 139.

Scott, W. R., \& Davis, G. F. (2015). Organizations and organizing: Rational, natural and open systems perspectives. Routledge.

Snyder, J. (2016). Learning Organization Models and Their Application to the US Army. Sri International Menlo Park CA Menlo Park United States.

Sorakraikitikul, M., \& Siengthai, S. (2014). Organizational learning culture and workplace spirituality: Is knowledge-sharing behaviour a missing link? The Learning Organization, 21(3), 175-192. https://doi.org/10.1108/TLO-08-2011-0046

Stead, J. G., \& Stead, W. E. (2013). Sustainable strategic management. ME Sharpe. https://doi.org/10.4324/9781315700533

van Breda-Verduijn, H., \& Heijboer, M. (2016). Learning culture, continuous learning, organizational learning anthropologist. Industrial and Commercial Training, 48(3), 123-128. https://doi.org/10.1108/ICT-11-2015-0074

Winkler, M. K., \& Fyffe, S. D. (2016). Strategies for Cultivating an Organizational Learning Culture. Washington, DC: Urban Institute.

\section{Copyrights}

Copyright for this article is retained by the author(s), with first publication rights granted to the journal.

This is an open-access article distributed under the terms and conditions of the Creative Commons Attribution license (http://creativecommons.org/licenses/by/4.0/). 